\title{
PROJECTS AND EFFECTS
}

\author{
The past, present and future of the Island of Nueva Tabarca \\ (Alicante, Spain) \\ [Received January $13^{\text {th }} 2017$; accepted February $11^{\text {th }} 2017$ - DOI: 10.21463/shima.11.1.12]

\section{Rosario Navalón-Garcia}

Universidad de Alicante <r.navalon@ua.es >

\begin{abstract}
Nueva Tabarca island is significant for the fields of Geography and Territorial Planning due to the changes that have occurred in its urban and social fabric and terrestrial and marine environment over the last three hundred years. Its most remarkable aspect has been the manner in which imposed urban projects have modified its form and function. From the construction of a planned utopian city to the tourist boom and urban speculation of the late 2oth Century, the island has been a testing ground in which residents have had to adapt to the changing conditions, reflecting successive trends in the region economic development.
\end{abstract}

KEYWORDS: Tourism, heritage, projects, management, sustainability.

\section{Introduction}

By their nature, islands have been considered laboratories for the study of how ecological and social systems function and, more recently, for the conservation of natural and cultural heritage (Mata, 2006: 185). Despite their diversity, and depending on their size, position, nature and evolution, islands usually present as differentiated terrestrial sites that are isolated by what is - within the terms of Island Biogeography at least - a "hostile environment" (Whittaker and Fernández Palacios, 2007, cited in Hayward [2016: 1]). Within this definition, they manifest as valuable and, at the same time, vulnerable systems. If the size of an island is small, the quantity and variety of natural resources limits its capacity for production and potential exchanges. Island territories of limited dimensions also tend to have a limited load capacity in all senses: environmental, social, economic or perceptual. This can lead islands to be considered as fragile and unsuitable for the implementation of activities such as tourism that utilise and consume natural and human resources without the risk of generating serious environmental and social imbalances, especially when there is an economic mono-specialisation around this activity. On this basis, this study aims to analyse the small island of Nueva Tabarca located opposite the Costa Blanca tourism region (in Alicante, Spain) - in order to show how people might best adapt to the conditions of the physical environment based on proposals and projects that have built a complex but essentially dual reality over the centuries. The island's small size and its insular condition, which gives it a relative isolation from the adjacent mainland, make it possible to understand some of the social and environmental processes that shape tourist destinations on much of the Spanish Mediterranean coast more generally.

Shima <www.shimajournal.org> ISSN: 1834-6057 
I am interested in a study approach that addresses the reality of this small island from an integrated perspective, ie as the result of human interaction in the territory that, adapting to the changing needs of society throughout history, has generated a cultural landscape whose perception and symbolic value continues to evolve. Landscapes change because they are expressions of natural and cultural forces in the environment (Antrop, 2005) and, therefore, the character and intensity of the mutations recorded will depend on the general dynamics that dominate at each historical moment. In this article I consider three periods that illuminate analyses of Nueva Tabarca: the traditional landscapes before the changes that began in the 18th Century, the landscape of the 19th and 2oth centuries, and the new landscapes we might identify as postmodern. For the present work, these three stages can be understood as marking three key moments: a) the state of the island prior to the island's development as a fortified enclave and a place for defensive control that forever changed the island; b) the period after the project stalled, leaving the resident society to its fate and pushing it to develop diverse strategies for self-subsistence; and finally c) the stage that reflects the national dynamics towards the tourist development. The combined effect of these different factors makes the perception and assessment of the territory change as well as the way in which the available resources are used and managed.

In undertaking this temporal analysis, various documentary and bibliographical sources have been selected with the aim of discovering aspects of the human use of the island. Despite its proximity to Alicante and the uniqueness of the island enclave, there are few scientific texts about the location that go beyond the provision of specific historical facts. For this reason, documentary sources have been examined for specific information that describes the living conditions of the island's inhabitants over time. In addition, the plans and projects that have been proposed for this location have also been a source of essential information. It seems clear that, sometimes, the geographical determinants of the territory have not been taken into account as a key factor for the real application of those plans. Direct observation and interviewing of some of the local social agents complete this analysis with regard to the feasibility of the most recent proposals for future development.

\section{Nueva Tabarca}

The island is located in the Mediterranean Sea, facing the south eastern Spanish coast, eight kilometres south east of the town of Santa Pola and twenty two kilometres south of the city of Alicante, which administers it (Figure 1). It is, in fact, an archipelago that consists of a main island (that was known as Planesia by the ancient Greeks, Isla Plana ${ }^{1}$ by the Romans, New Tabarca since the 18 th Century, Tabarca for visitors or simply l'Illa ${ }^{2}$ for its present-day inhabitants. The main island is surrounded by the islets of La Cantera, La Galera and La Nao, along with numerous rocks (Negre, Roig, Cap del Moro, Sabata or Naveta). It has a NW-SE orientation and an elongated shape with a narrowing in the western third, being 2050 metres long and having a maximum width of 400 metrs (Marco, 2012: 16). It is the largest and only inhabited island of the Valencian Region with an approximate area of 0.3 square kilometres and has a fundamentally flat topography that varies between 5 and 15 meters above sea level. It has a low cliff coast of around 5

\footnotetext{
${ }^{1}$ Literally "Flat Island", reflecting its topography.
}

${ }^{2}$ L'Illa being "Island" in the Valencian language. 
metres high, some pebble beaches and only one sandy beach, located in the isthmus area. The terrain of the island is divided into two areas: the area to the west where a small walled citadel was located that has now become a urban space that offers tourism services and the remaining two-thirds comprising an undeveloped area called the Campo ("countryside") that was initially supposed to be for agricultural use but is now lies in an unproductive state.

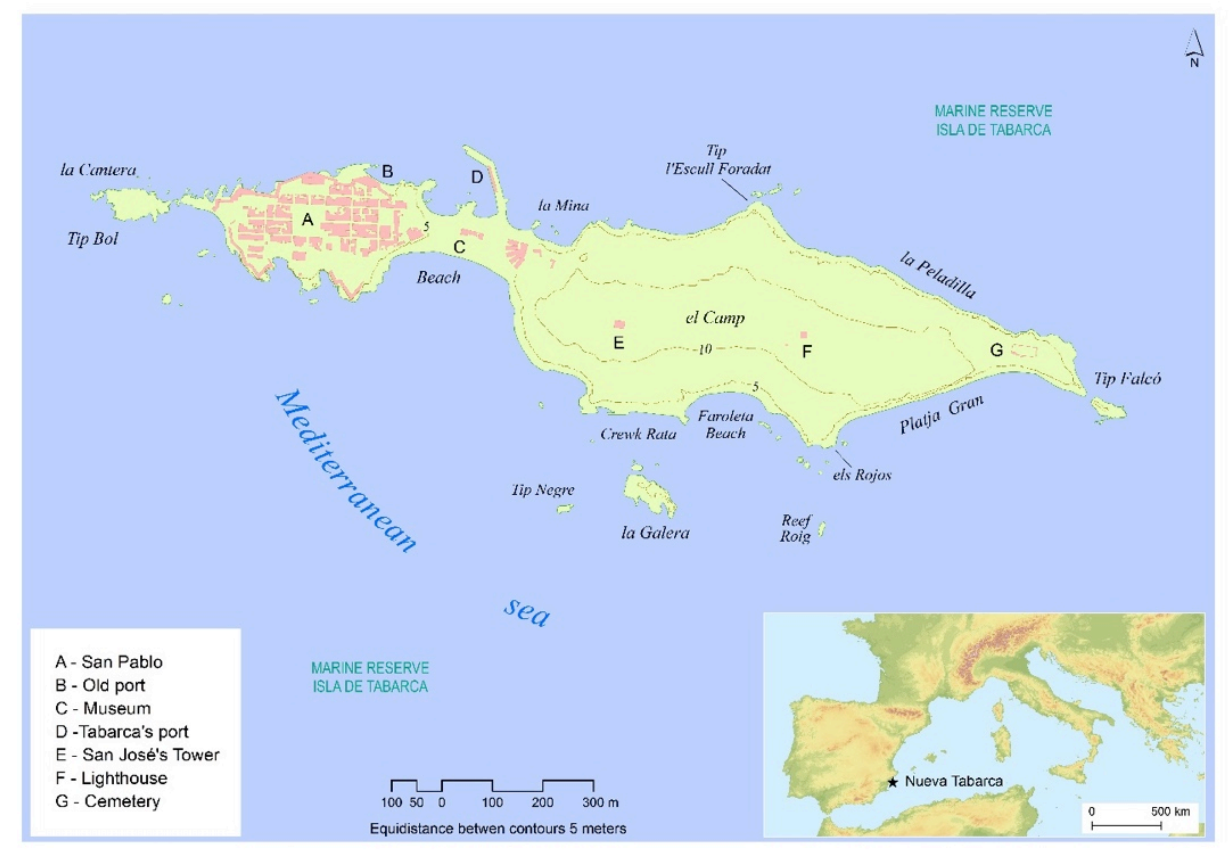

Figure 1 - Map of the location and topography of Nueva Tabarca (compiled by the author from Cartography BCVo5 [1: 5000], 2005)

The island has a dry Mediterranean climate with mild temperatures and very little precipitation throughout the year. Its average annual temperature is $17^{\circ} \mathrm{C}$ (maximum $35^{\circ} \mathrm{C}$ in August and minimum $5^{\circ} \mathrm{C}$ in January), rainfall is very irregular throughout the year, not exceeding $300 \mathrm{~mm}$ per year, and the average wind speed is low. These features may provide excellent climatic conditions for tourism but are otherwise not conducive for inhabitation given the absence of water that limits the viability of forest cover, agriculture and human settlement. The waters around the island comprise the first Marine Reserve to be declared in Spain (in 1986) and the reserve has served in subsequent years as a model for the declaration, development and management of new protected marine areas. The permanent population presently numbers around fifty-five people. While the inhabitants carry out some traditional fishing practices (within the provisions of the marine reserve) they are mainly dedicated to tourism. The island's natural and cultural heritage have been recognised and provides important attractions that merit consideration with regard to aspects of conservation, recovery, management and/or their sustainable use for tourism purposes.

In 1964 the island won a Historical Heritage and Assets of Cultural Interest Award (the highest Spanish recognition of heritage value), awarded on account of its walled citadel in 1964. The citadel dates back to the time of Carlos III (1759-1788) and its design reflects

\section{Shima Volume 11 Number 12017}


the concept of the utopian city developed during the Baroque era in the 18th Century. It was initially populated by prisoners from Genoa who were rescued by the Spanish crown from their Algerian captivity on Tabarka island, off the coast of Tunisia (hence the island's current designation as Nuevo [new] Tabarca). The island has an intriguing intangible cultural heritage, not only in the urban setting but also in the rest of the island, which shows the population's necessarily close relationship with the hostile natural environment in which they sought to survive. In addition, another notable heritage is linguistic, with some variations of Catalan and traces of Ligurian language being present in the island's dialect (Llorca, 2012).

All these traits, together with aspects of its recent history, form a distinct location that allows for integrated planning of natural and cultural heritage, tangible and intangible. Its singularity, derived from its location, nature and historical development, has allowed for the development of diverse projects and has also been a source of inspiration for artists of various kinds. However, today its identity is increasingly affected by tourism consumption that pays scant attention to its heritage assets and and landscape, in preference to focussing on the superficial enjoyment of its climate and coast.

\section{Historical precedents for a complex reality}

On clear days you can see an important part of the coast of Alicante from the island: 52 $\mathrm{km}$ north to the cliffs of the Sierra Gelada in Benidorm (Alicante) and $61 \mathrm{~km}$ south to the Mar Menor (Murcia). The vista of more than $100 \mathrm{~km}$ that reaches into the mountainous circle of the Alicante Province's inland area has historically given this island a strategic role in monitoring possible invasions or external attacks on the coast. This situation, together with the proximity to the mainland and the richness of its waters for fishers, has provided the basis for human settlement, in various periods, despite the absence of drinking water for human consumption. Evidence has been found of an ancient Roman occupation (3rd Century) and of Roman wrecks off the coast. There is also a written record from the medieval period (12th Century) that states the need to provide the island with defensive and surveillance constructions to avoid its use as an anchorage for pirate ships coming from North Africa. This aspect of regional life continued to be significant. When pirate attacks were launched on the coast in the 16th Century, a system of watchtowers was introduced to warn the population of Elche and Alicante areas about possible pirate attacks.

Written and archaeological documentation indicates that the island was visited over the centuries and occasionally inhabited but did not have a permanent occupation until its colonisation in the 18th Century (Pérez Burgos, 2012) - undoubtedly due to the conditions of the island not being conducive to self-sufficient settlements. The circumstances outlined above led to the planning of a fortified settlement on Nueva Tabarca (Figure 2) whose project, designed by the engineer Fernando Méndez de Ras, was inspired by utopian approaches developed during the Enlightenment, with its planning extending beyond the city and incorporating the broader territory, but had a very different basis to that outlined in Thomas More's Utopia (1516) by being a settlement with a military character. This project was conceived as a unique, rational, complete, self-sufficient and autonomous entity within the possibilities that the environment allowed (Varela, 2007). The main factors that led authors such as Varela, (2007), Pérez Burgos (2012) and Canales and Romero (2014) to describe it as a utopian project concerned matters of state:

Shima Volume 11 Number 12017 
- In the middle of the 18 th Century the Spanish crown defined its policy towards North Africa and prioritised the establishment of better defences of its cities, including the construction of military posts along external walls. Reflecting this, in 1760, the Governor ordered the construction of various military installations on Isla Plana, carried out by teams guarded by military escorts. A military garrison was planned on the island because of its geostrategic situation, allowing it to monitor and repel the corsair incursions along the coast that were proving so damaging to regional security and prosperity.

- Along with the above, and within the context of the rationalism that was dominant in most of Europe, the creation of special sections within the army led to the development of a body of military technicians with knowledge of engineering and architecture. Motivated by the reformist policies of late 18th Century, that body facilitated the development of various new settlements in Spain, particularly in previously uninhabited territories. Amongst all of them, the only one of significantly insular character was the nucleus of San Pablo, located on Isla Plana (Canales, 2012).

- A specific event required action: the desirability of rescuing a group of 69 families of Genoese origin from captivity. The families had been captured by Algerian corsairs and held on the island of Tabarka off the coast of Tunisia, which was under Spanish flag at that time. They were released after mediation and the payment of ransom by a religious order and became the population needed to colonise the small and strategic island that had been already projected.

Thus, coincidentally, three different but related concerns were brought to the attention of King Charles III: the deplorable situation of the Genoese captives; the need to confront the attacks of Berber piracy in Algiers and Tunisia; and the proposal for a large military and civil project to be developed on San Pablo. On this basis and with all the relevant permits, Mendez de Ras projected a rectangular city surrounded by walls, following the Renaissance tradition, with an orthogonal plane and the axes organised according to the cardinal points structured around three squares. The main settlement, with exnovo constructions for the population and the troops, were intended to be located on the smallest part of the island, along with, batteries and defenses, three access points, quarters and warehouses for the troops and crafts facilities (Varela 2007). On the opposite end of the isthmus - the most extensive part of the island - the fields would to be used for crop plantation and would be articulated by a central road. In the Cantera (quarry) area, from which the stone was extracted for the buildings of the island, another fort was planned to ensure the safety of the Western flank of the city.

This enclave was intended to be self-sufficient and organised as a clearly hierarchical society but there were certain fundamental flaws to its conception. On the one hand, the limitation of available space, the high frequency of sunshine and winds blowing over a largely flat topography made fertile soil very scarce and the island largely unsuitable for the agricultural activities that were fundamental for the sustainability of the project. This issue was further aggravated by innumerable problems concerning supply, mainly of the water resources needed for the population and agriculture but also firewood, given the absence of trees on the island. Although wells and cisterns for water storage were built in strategic locations, inside and outside the citadel, the absence of rainfall in this area required the provision of water supplies from the coast (Pérez Burgos, 2012), limiting the feasibility of the island's settlement.

Shima Volume 11 Number 12017

-148 - 


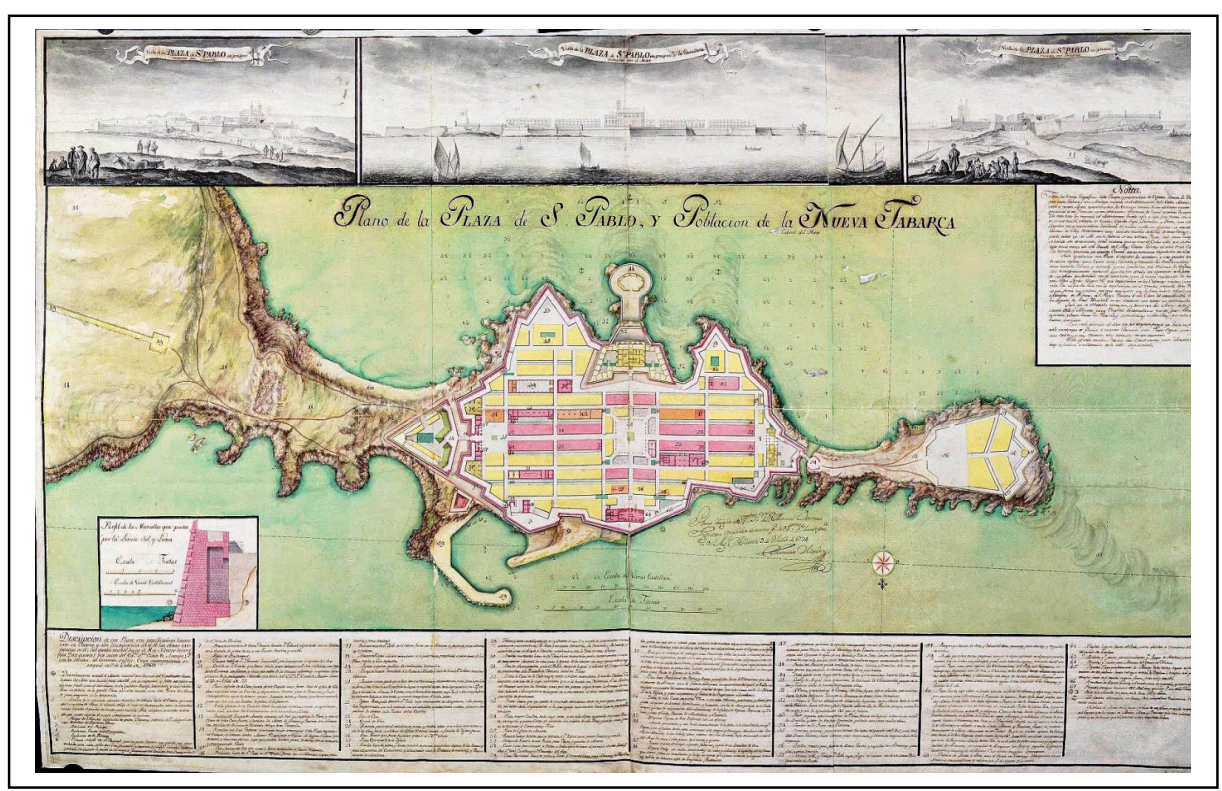

Figure 2 - Map of Nueva Tabarca by Fernando Méndez de Ras, 1775 (Source: Servicio Geográfico del Ejército)

Taking into account these serious difficulties, the sustainability of the project was imperiled by the weakening of political impetus to support it following the peace agreement signed with Algiers in 1784 that led to the reduction of Berber piracy and changed the orientation of Spain's policy towards the Mediterranean and Africa. Thus, the geostrategic function of Nueva Tabarca was no longer so relevant and the military garrison intended to inhabit the island never eventuated. The population was limited to the Genoese tabarquinos relocated from the Tunisian island of Tabarca who had to rely on artisanal fishing to subsist. As a consequence, the original terms of the project were never completed. The plight of the settlers is apparent from the chronicles of travelers that describe the harsh lifestyle and senses of abandonment felt by the people who lived there who could not exercise their own free will to leave and, consequently, perceived themselves as trapped on a barren island without a future (Soler, 2012).

Despite this sad end to what was intended as a utopian project, something positive has remained, since practically all the historical resources of the island have a potential value for tourism: the city fortified with walls and monumental access doors, defence batteries, houses, barracks, stables, underground vaults, a shipyard, church, Governor's house, wells and cisterns for rainwater collection and ovens. There is evidence that some studies and reports were requested in order to approve the demolition of these heritage resources - given the obvious inefficiency of the investments made - but fortunately this destruction was not approved and today we can study this heritage as part of a cultural landscape worth knowing and showing.

\section{Shima Volume 11 Number 12017}


III. The traditional landscape of the Island during the 19th and early 2oth centuries

After the city project was abandoned the population was forced to adapt to the island's harsh conditions with no water, firewood or naturally fertile soil. The descriptions of the island landscape made above suggest that while the Campo was modified by marginal agricultural activity in the 19th and 2oth centuries, its current appearance, dotted with xerophytic thorny shrubs, capable of growing in arid areas, may have been typical of the landscape initially inhabited by the settlers. In this area, the only buildings of any historical interest still standing are the towers of San José, the lighthouse and a ruined farmhouse. The farmhouse is the only element that allows us to understand the precarious subsistence economy that sustained the island along with imports from the adjacent coast. According to Lozano Quijada (2012), in the 1940s farm buildings were part of a set of farm and stable buildings around the central constructed area. The lack of water made it necessary to build cisterns all over the island and also in this area. The main crops cultivated this part of the island were cereals such as barley, wheat and oats, along with barilla ${ }^{3}$, some figs and pods of optunia (prickly pears). These crops were located near a house that also had a small orchard. The viability and profitability of these crops was quite low. Given these conditions, it seems logical that the activity that has marked the occupation and the evolution of the tabarquinos throughout the 19th and 2oth centuries has been fishing, and, in particular, the capture of tuna by fish traps. The link between this activity and the population of Nueva Tabarca is such that some authors claim that there is a parallelism between the evolution of the population on the island and the volume of catches (Parodi, 2012).

The tuna traps consisted of a set of nets and boats that created a submerged structure in which the fish were confined and landed. The traps were a labyrinth of esparto and hemp fibre that intercepted and concentrated the migratory fish and allowed them to be caught en masse. The Nueva Tabarca trap was installed off La Galera island (to the immediate south of the main island) and during the mid zoth Century had the largest volume of catches in the whole province. Its construction involved practically all of the island's inhabitants in the different tasks: the hauling in of catches, the fabrication and repair of nets and structures, boat maintenance and preparation and, initially, the sale of the catch (although the latter activity was later relocated to areas on the mainland coast). The volume of fish caught and number of proportion of islanders involved in the catch peaked at the end of the 1940s (shortly after the island's harbour was expanded) with the catch declining until 1960, when the practice ceased.

Although tuna fishing is no longer practiced today, there are still toponyms on the island that reference the tasks associated with this activity. In addition, there are numerous folkloric accounts that describe the exploits of the sailors who had to confront large animals such as cetaceans or sharks as part of their livelihoods (Parodi, 2012). These stories can be considered part of the island intangible heritage that merit preservation. Since the abandonment of tuna fishing, there has been a gradual reduction in the permanent population (Figure 3). Now there are 55 inhabitants registered and only 10-15 of these remain on the island in winter, ${ }^{4}$ the rest of them living in Santa Pola and other mainland towns until summer when the population multiplies considerably (in addition

\footnotetext{
${ }^{3}$ Salt-tolerant plants that were the primary source of soda ash

${ }^{4}$ Information supplied in nterview with the Local Police Department in May 2016
} 
to the thousands of visitors who arrive during the summer months). With the disappearance of tuna trapping in the 196os, the decline of the island was aggravated not only by the loss of population but also by the evidence of infrastructure deficiencies, such as the lack of electricity and water supply.

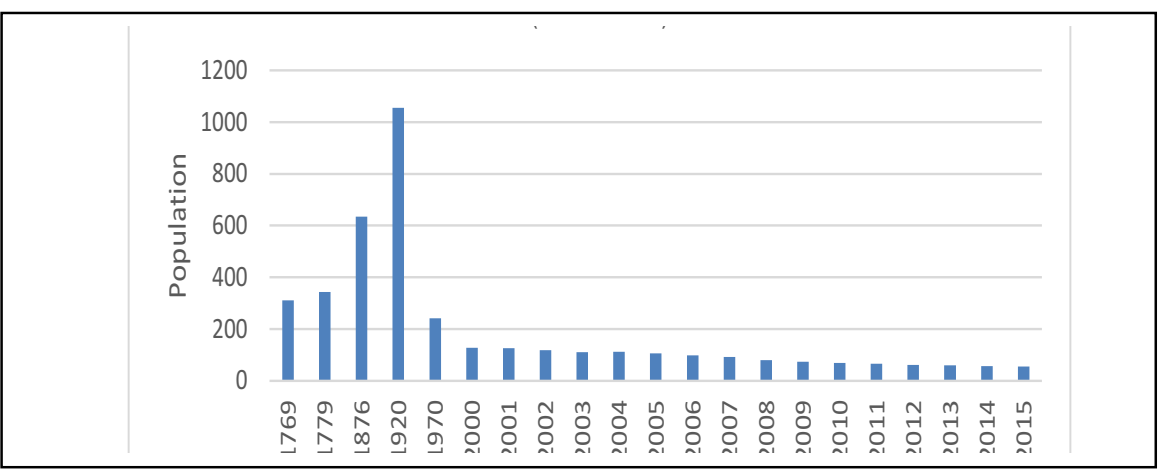

Figure 3 - Development of the population in Nueva Tabarca (1769-2015) (Source: Compiled by author based on INE figures)

The overview of this period shows that the unfinished urban landscape was practically intact and the Campo is the area that changed most as the result of agricultural activities that had to adapt to adverse environmental conditions. The port and maritime area was greatly altered due to the importance of the trap fishing activity which, however, was also ephemeral and was displaced by an activity that would overwhelm the occupations of its inhabitants: tourism.

IV. A new stage for the development of the island of Tabarca: tourism as a 'solution'

In the absence of other subsistence options, and reflecting the intensity of tourism along the adjacent Costa Blanca, some local fishermen responded to the end of the tuna fishery by adapting their boats for new recreational uses or bought new ships to make transfers for visitors who began to be interested in this island, attracted both by the sun and the beach, but also by sport fishing activities. Empty houses were repaired and some bistros and shops were opened to serve the growing number of visitors. The island's port, which had been expanded in 1944, facilitated the comfortable arrival of a substantial number of boats. Despite the existence of legal mechanisms pertaining to such developments, all this activity occurred without planning (as it had elsewhere in many other destinations on the adjacent coast). During the first stages of tourism development along the Spanish coast, the legal framework for territorial and urban planning legal in the municipality of Alicante was limited to an Urban Plan of Alignments. In that plan, the use of land was established for the whole territory but was proposed based on a concentric zoning around urban land. The proposal was not adapted to the needs of the municipality nor to coherent planning with the available resources but rather seemed more concerned with spontaneous growth (Navalón, 1995). Approval of plans depended on the Ministry of Housing, located in Madrid and, as a result, the process of approving the new urban plans that should set future development guidelines (in line with the 1956 Land Law) was

\section{Shima Volume 11 Number 12017}


slow and difficult. Therefore in Alicante, as in other places in Spain, proposals of partial plans - which were advanced ahead of integrated territory planning - were frequent.

Such an approach appeared likely to happen in Nueva Tabarca in 1962, when a company from Madrid proposed the purchase of two thirds of the island with the objective of developing a macro-tourism project on the island. According to documents presented by the company that took the initiative, the Council was asked to carry out the preparatory studies to develop a partial plan that would cover all the island territory. The proposal included the purchase of the corresponding lots:

with the aim of carrying out a total urban planning of the Island, to equip it not only with the necessary facilities (such as water, electricity, etc.) that modern life requires for a normal and adequate daily life and sanitation of the population, but also to restore and preserve the elements of existing artistic and historical interest, rebuilding and carrying out the existing project dated 1770, designed by the Military Engineer D. Fernando Méndez. (Parodi, 2015: author's translation).

The plan proposed the construction of a yacht club, water skiing facilities, tennis courts, stables, bowling greens and a heliport among other services (ibid). All this, together with the construction of accommodation facilities for 800 people, was a reflection of a developmental trend that involved similarly grand projects along the Costa Blanca.

In this case, and others, the fact that some land tenants wished to take similar initiatives in order to profit from the perceived opportunities of tourism, caused delays and raised bureaucratic obstacles that served to cool the transforming cravings of the company. The project would have involved the drastic alteration of the island's natural landscape and its historical heritage but, fortunately, the proposals were rejected.

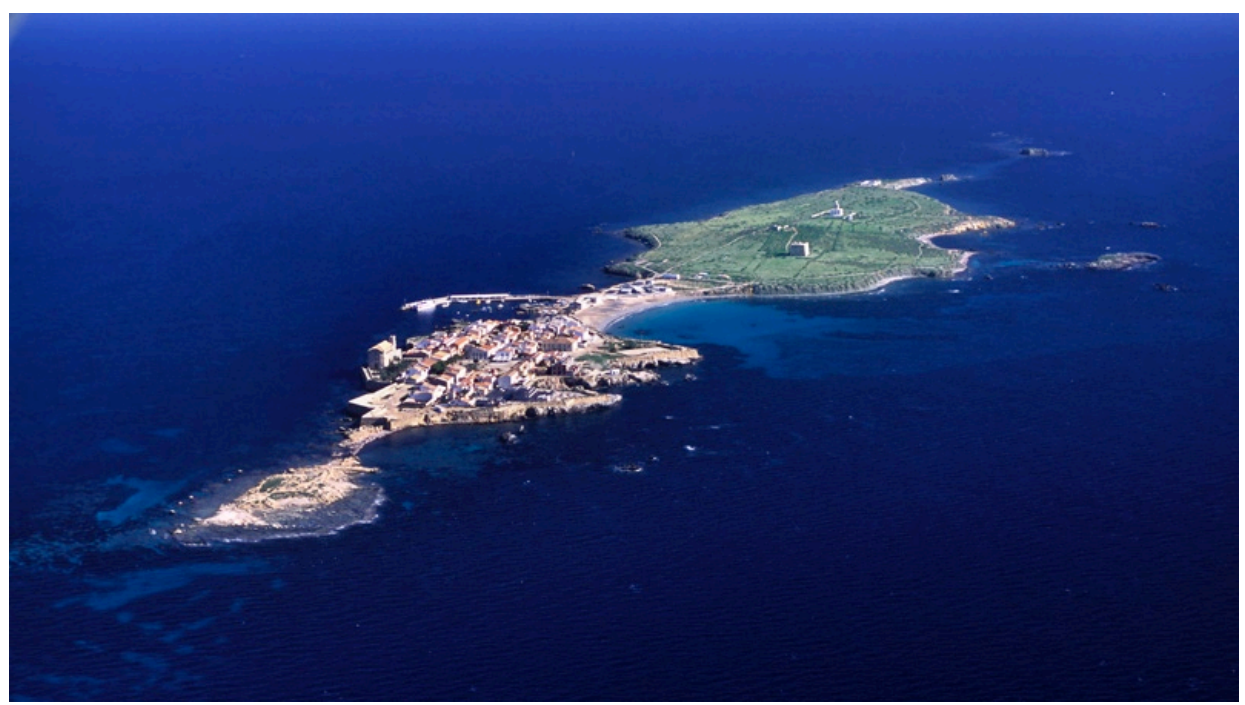

Figure 4 - An Aerial view of of Nueva Tabarca (Source: http://www.alicante.es/es/contenidos/isla-tabarca) 
This project is a good example of the urbanisation pressures - from foreign companies or from land owners - that result in many places of natural and cultural value ending up being drastically transformed or even disappearing. In the province of Alicante, with a predominance of dry climate and warm sea and with a heterogeneous agricultural yield, tourism seemed to be the solution to the problems of its residents. That was also the perception in the island of Nueva Tabarca, which was eager to receive attention from the public authorities. Probably as a result of the aborted development project, the declaration of the fortified territory of Tabarca as a Historical-Artistic site occurred in 1964. Two decades later, in 1986, its marine environment was declared as the first Marine Reserve in Spain. These two facts, together with the hope of tourism development, form the three vectors that could set a new direction for the socio-economic development of the island.

\section{The Tabarca marine reserve: a pioneering example of management in difficulties}

Around the mid-2oth Century the main economic activities on island were traditional fishing and tourism, which constituted a growing presence on both land and the maritime space that surrounds the island. This situation led to consideration of the compatibility of both functions so that only very selective fishing gear could be allowed within the protected area and other certain sectors and only for fishermen belonging to Tabarca Fishermen's Cooperative. Given the tension between the conservation of traditional practices and the development of new functions linked to recreational and tourist use, a 14 square kilometer area around the island was declared a Marine Reserve in 1986 with the objective of protecting the ecosystems and species of the zone, as well as managing the resources of the traditional fishery (Ramos and Bayle, 1990). With fifteen boats registered in the Fishermen's Cooperative, with crews of 2 or 3 people, traditional fishing has been practiced from then until now at a level recognised as sustainable and environmentally friendly. Following its declaration as a protected marine reserve, the Nueva Tabarca zone has proven that better management of marine resources and fisheries can increasing the production of fisheries developed around the protected area, since the cessation or reduction of catches within the protected area produces an increase in abundance and size of the specimens (Forcada, 2012).

In addition to its objectives of promoting sustainable and respectful fishing, the Marine Reserve management plan involves developing activities to inform the local population as well as to raise general public awareness of marine resources. In addition, adapting infrastructures to complement their basic task with research - such as promoting the adaptation of the lighthouse building as a research center or the launch of environmental education campaigns open to residents and visitors - might be also be future projects. Obviously, all these tasks require adequate funding to hire sufficient staff for the infrastructure maintenance as well as coordination and support by all responsible administrations at different levels. Unfortunately, in recent years the cuts associated with the global financial crisis but mainly the lack of political will have impacted the objectives' effectiveness. This hardly seems appropriate for the maintenance of an over 30 year-old project which has been seen as an exemplar of marine zone management in many other places. 


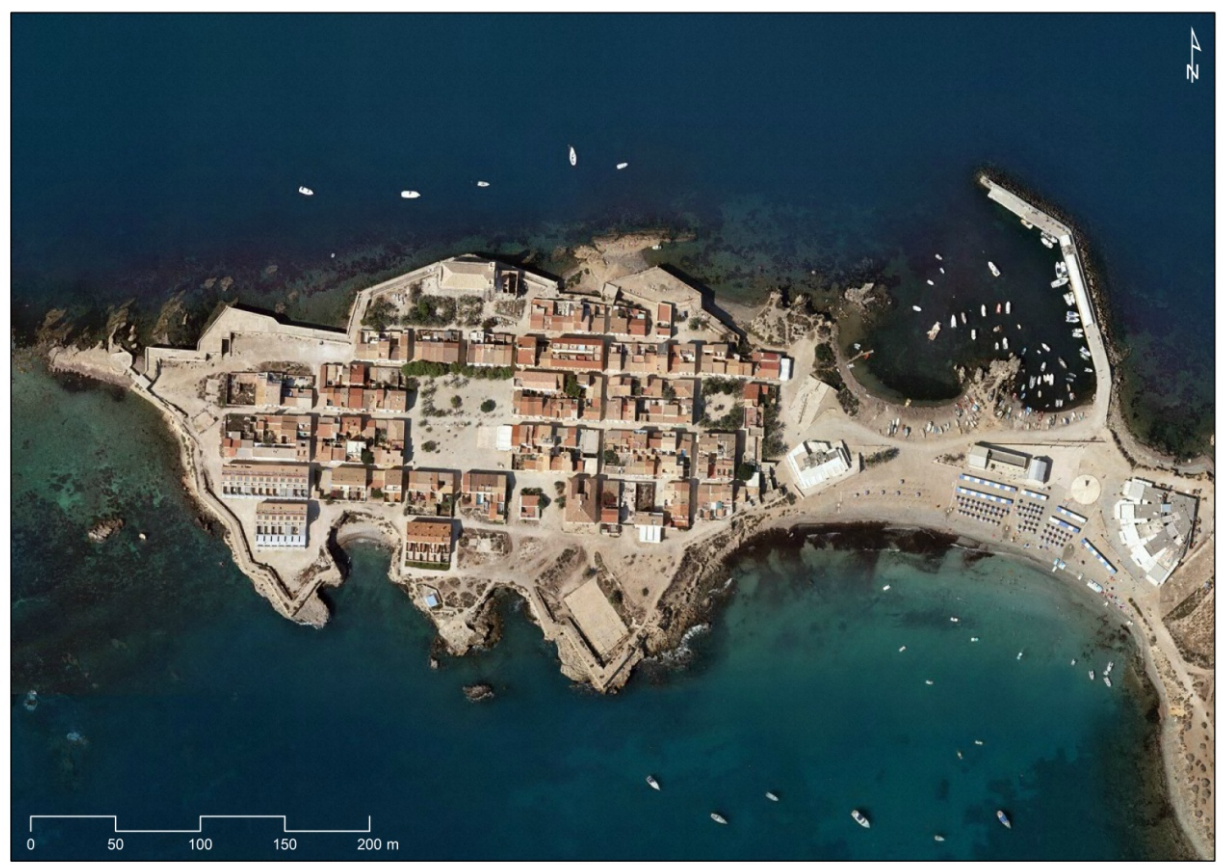

Figure 5 - Image of the isthmus of the island that separates the historic center of El Campo. In this small and complex space we find the centre of fishing activities, along with the passenger port, tourist beach area and related nautical activities. (Source: Valencian

Cartographic Institute, 2007)

The protection of cultural heritage in a context of tourism-related real estate pressure

As previously mentioned, in response to the transformational pressure of tourism and in recognition of the island's heritage assets, the island was declared an Historical-Artistic site in 1964. However, this de facto declaration had little significance from the conservation and heritage management point of view because of the imprecision of its determinations on the buildings to be protected or how it should be done (Martínez Sanmartín, 2012). After legislative changes in terms of protection at the national and regional levels - in 1985 and 1998 respectively - the island was categorised as a Cultural Heritage Site (BIC) $)^{5}$ with regard to its Historic value. Subsequent developments also allowed for the inclusion of the intangible assets and values with ethnological character within its designation.

Despite the importance of this recognition, it should be emphasised that the effective protection of the island's heritage required not only the declaration adopted in 1964 but also the development of a Special Plan for the island in the form of a detailed document that would complete municipal planning. The drafting of this foundational document commenced in 1969 but, due to various delays, was not finalised and adopted until twenty years later, in 1984. Although the initial intention was to protect the whole site, only the

${ }^{5}$ The highest level of protection for movable or immovable properties awarded by the Law of Spanish Historic Heritage according to their historic and social relevance or singularity.

\section{Shima Volume 11 Number 12017}


most relevant constructions from the original project were protected: the walls, the governor's house and the church. This left aside the original residents' housing and its heritage manifestations - immaterial, furniture and real estate - which have been lost, together with traditional ways of life, and replaced by customs and uses that are better adapted to tourism needs.

From the initial tourism boom onwards, demand for what is variously termed 'residential tourism' or 'lifestyle migration' on the Costa Blanca (see Mazon, 2006) impacted on the island, leading to the gradual replacement of traditional houses by constructions of different volume and structure that have affected the site's homogeneity and the conservation of its essence. Although it was not the first construction project linked to tourism - since there were precedents that did not come to be executed - the clearest expression of this urbanising pressure occurred in 1994 with the approval of a project that included new blocks of houses within the fortified enclosure. The absence of a clear regulation that defined permissible actions and the broad context of tourism real estate development in the Spanish Mediterranean ended up leading to the abandonment and replacement of the traditional architecture in the town by other types with little or no recognition or conformity with the previous structures, distorting the whole site. Proposals for building semi-detached bungalows that broke the site harmony were also executed. In fact, a set of villas was built illegally, taking advantage of the tortuous process of urban planning in the municipality of Alicante. Fortunately, as those constructions violated the Law of Coastal Protection, they have recently been demolished.

In the same vein of apparent improvisation, the urban proposals promoted by Alicante City Council to improve the public space of the island do not seem to respect the integrity of its heritage. In fact, the project for adapting and urbanising the isthmus area developed in 1994 was quite controversial, as several social groups were concerned about conservation. At that time, the only existing construction was the old tuna trap that might have been restored. However, the project included a building with administrative and service functions in which The New Tabarca Museum, proposed with a design that contrasted drastically with the patrimonial set, was also located. A fan-like development was incorporated in this area to host a group of restaurants whose scale and volume, as in the previous case, broke with the pre-existing horizon line, which was situated at a lower level between the two lateral spaces of the island, therefore altering visual perception of the whole site.

In response to these and other transformative pressures, and with the intention of preserving the island's heritage from future irreversible actions, the 1984 Special Plan was suspended in 2001 until the entry into force of a new ordinance that, even today - in 2016 has not been approved due to various political reasons. It seems evident that the new Special Plan for the Nueva Tabarca should respond to a comprehensive management criterion, being able to articulate actions for the protection of the natural and cultural heritage and the landscape and favouring an adequate use of the territorial resources. The role of tourism management in this Special Plan should contribute to sustainable development from an ecological, economic and social point of view.

Tourism in Tabarca today: challenges for the management of the island's territory

Nowadays economic activity on Nueva Tabarca is focused almost exclusively on tourism with the fishing sector being maintained by very few people. The island's proximity to the 
coast of Alicante - almost an urbanised tourism continuum with mature sun and beach destinations as Benidorm - can be understood in a dual way, as both positive and negative. On the one hand, proximity allows resources and services' provision and favours the arrival of visitors, who spend a few hours on the island to appreciate its heritage or to enjoy a unique experience in the only inhabited island or the region. On the other hand, this proximity has led to an attitude of temporality or seasonality from some residents, visitors and public administration that has affected the execution of some needed actions.

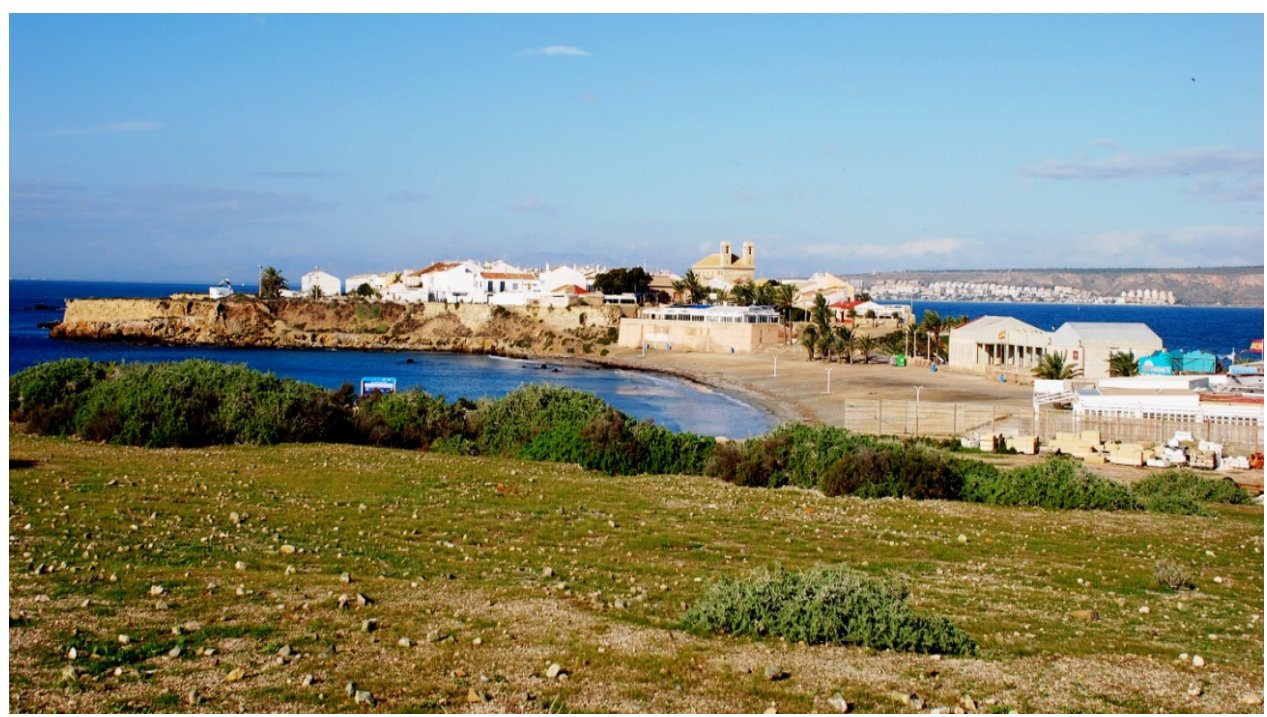

Figure 6 - Image from the El Campo towards the walled city (author's photo).

Nueva Tabarca can be regarded as an island of contrasts: almost uninhabited in winter, with less than twenty people, and saturated in the peak tourism season when there are around 3,500 visitors per day. One side of its territory is constructed and humanised. The other dominated by natural vegetation. Initially fully planned as an integrated urban and rural landscape, successive projects now overlap on the island without apparent coordination or order. It is an island where there are no roads because there is no traffic except some small service vehicles - but it has a congested port in summer, full of boats and catamarans that travel between the island and the ports of Santa Pola or Alicante, in addition to a multitude of private boats, boats and yachts that dock in the anchorage areas allowed by the Marine Reserve. In sum, it is a place of interest from the natural, cultural, social and economic point of view, like few others. More than 50 years have passed since its declaration as a Historical-Artistic site in 1964, however much remains to be done on the island. The infrastructure for potable water, electricity and purification has certainly been completed, albeit very recently, but a number of projects are still in the pipeline (overseen by the Alicante administration in coordination with other national or regional authorities involved) related to issues such as the environment, culture, coast, or interior. From the heritage point of view, several actions foreseen long ago have already been completed, such as paving the floor of the historic centre, the restoration of several sections of wall and ramparts damaged by successive storms, the cleaning of the artillery vaults so that they can be visited and the restoration of the church of San Pedro and San Pablo. However the reconstruction of the priest's house or the school that was annexed to this construction has

\section{Shima Volume 11 Number 12017}

$-156-$ 
not yet been completed. At the beginning of the 21st Century, in 2002, the Museum of Nueva Tabarca was inaugurated to provide information about the island's history and heritage. In 2006 the CEAM Tabarca Environmental Education Center also opened in order to collaborate in environmental education and training of any group interested in safeguarding heritage values. There have also been further activities concerning tourist signposting in the Campo area. There are three paths in the island: an urban path in the interior of the citadel, the urban path that runs all around the perimeter of the Campo (that has already been signposted) and a submarine path that is proposed through the island's rich marine spaces.

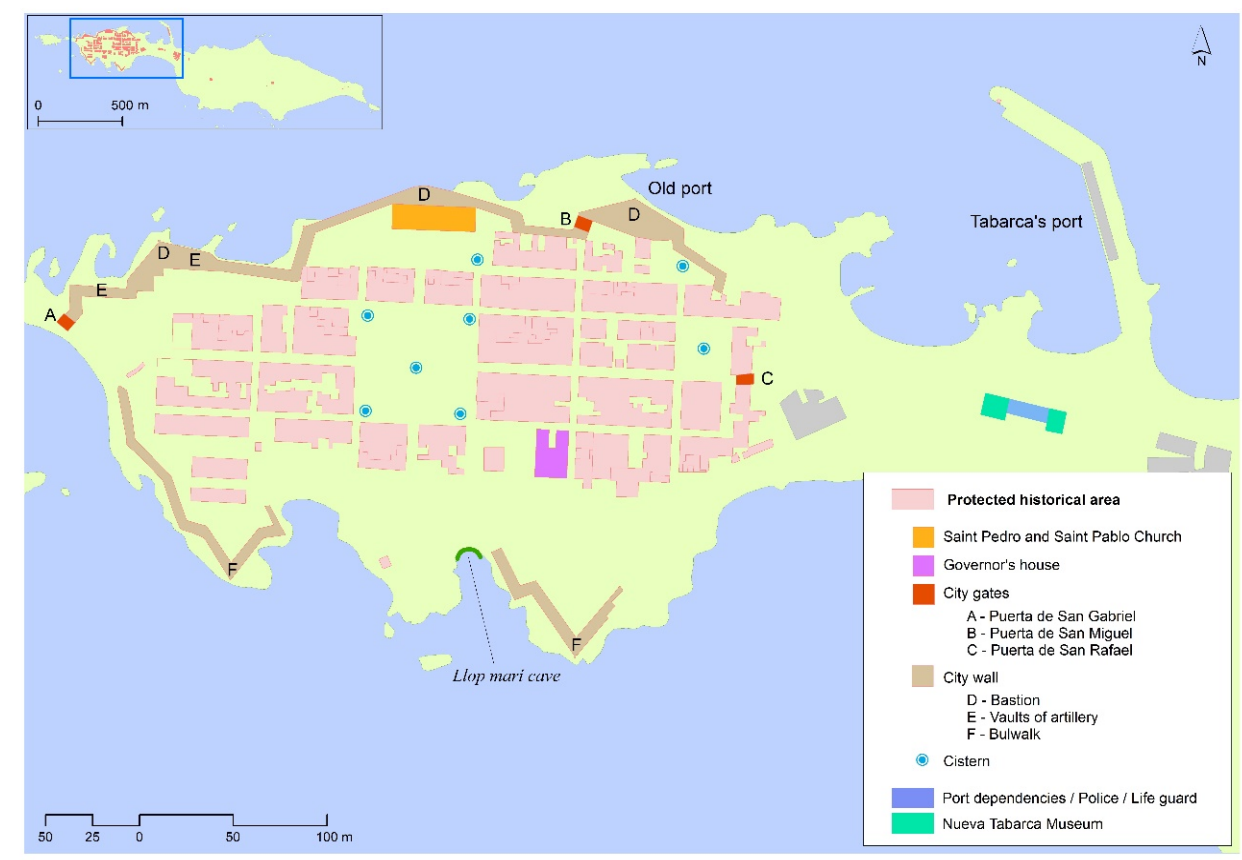

Figure 7 - Tourist resources of the island of Nueva Tabarca (Source: Compiled by the author)

It may seem that a new era has begun promising the immediate approval of a new Tabarca Island Special Plan and the reconstruction of ruined properties in the uninhabited area of the Campo (such as the farm house or the possible recovery of the Torre de San José - now owned by the Ministry of Interior - for cultural uses), as well as the provision of elements of public interest for the lighthouse. However, in the author's opinion the conception of these investments is not entirely correct. Although necessary actions are proposed I believe that the management and maintenance aspects of these actions are being neglected.

In my view, the most relevant matter is related to the tourism opportunities offered around the heritage resources (Figure 5). It has been reiterated how both natural and cultural heritage deserves the highest level of protection and visitors are often interested in historical and natural assets. However, beyond the premises of the Nueva Tabarca museum and the recent signposting panels of the natural and urban trails, there is minimal

\section{Shima Volume 11 Number 12017}


interpretation of such assets. The museum itself is not open on continuous basis and there are no cultural or natural guided tour services on the island for those who may desire them. In this way, visitors arriving on the island can only walk, go to the beach, behold the scenery or eat in one of the restaurants but do not have the possibility of easily experiencing island heritage. In my opinion this is one of the main weaknesses of the Tabarca tourism model. In spite of investments focused in heritage recovery, the absence of both future planning initiatives and the definition and management of real tourism products conditions the activity of visitors. That limits them to enjoying a passive experience related to the sun and the beach with no more recreational options. In the 21st Century, Tabarca continues to offer the three 'Ss': sun, sand and sea, elements that are more related to tourist preferences during the initial tourism boom than to present-day tourist needs and motivations. The island has failed to take advantage of the interpretive potential of its heritage and therefore loses the opportunity to respond to the needs and motivations of the current tourism market, which is more experienced demands other attractions linked to the enjoyment of experiences related to natural and cultural heritage.

\section{Conclusions}

The aim of this article has been to show how Nueva Tabarca has been the object of several projects aimed at developing comprehensive proposals that take advantage of its strategic situation. This evolution ranges from the conception of an almost utopian city that was the germ of the current Nueva Tabarca - abandoned shortly after its construction commenced, leaving its inhabitants to their fate - to the project of a sustainable and environmentally friendly destination in a convulsive economic and political context. Other plans for the drastic transformation of island landscape for tourism purposes were also developed during the developmental period. In all cases, the importance of development factors, such as water and energy supply, and the improvement of external accessibility have been ignored or devalued. Tourism development should go beyond a focus on immediately attractive resources and should seek ways to manage them efficiently through sufficient staff and an adequate budget for activities development.

Given current economic contexts it is perhaps inevitable that short-term economic goals prevail over all others in many tourist areas of the western Mediterranean. Speculative tensions over both territory and natural resources make it very difficult to implement sustainable proposals for the managed exploitation of resources. However, it is not an impossible scenario since some illegal constructions on this island have already been demolished following community pressure. What seems evident is that the island's sustainable development demands a comprehensive approach not only in environmental terms but also in economic and, above all, social ones; in a balanced way capable of satisfying residents, visitors, investors and all those responsible for its viability. In order to achieve this goal, it will undoubtedly be necessary to implement a coordinated planning process at different administrative levels and from different perspectives. This is the means for the Special Plan for Tabarca Island to be adopted and for valuable resources to be maintained and made accessible for future visitors. 


\section{BIBLIOGRAPHY:}

Antrop, M (2005) 'Why Landscapes of the Past are Important for the Future', Landscape and Urban Planning n7o n1-2: 21-34

Canales, G and Romero, O (2014) 'La población de Nueva Tabarca, Un proyecto ilustrado de fortificación insular', in Canales, G, Pérez, J.M and Lozano, F (2014) Nueva Tabarca, un desafío multidisciplinary, Alicante: Instituto Alicantino de Cultura Juan Gil-Albert: 85-108

Defert, P (1967) 'Le Taux de Fonction Touristique: Mise au point et critique 5', Les Cahiers du Tourisme Serie C n5

Fernández-Latorre F.M and Díaz del Olmo, F (2011) 'Huella ecológica y presión turística socio-ambiental - Aplicación en canarias', Boletín de la Asociación de Geógrafos Españoles n57: 147-173

Forcada, A (2012) 'La pesca artesanal en la Reserva Marina de Tabarca: una alternativa sostenible', Canelobre - Revista del Instituto Alicantino de Cultura Juan Gil-Albert n6o: 182195

Hayward, P (2016) ‘Towards an expanded concept of Island Studies', Shima vı nı: 1-7

Llorca Ibi, F.X (2012) 'La llengua tabarquina: de Gènova a Alacanti', Canelobre - Revista del Instituto Alicantino de Cultura Juan Gil-Alberto n6o: 206-215

Lozano Quijada, A.A (2012) 'Entre el mar y el cielo, el tercer hito del campo', Canelobre Instituto Alicantino de Cultura Juan Gil-Albert n6o: 196-205

Marco Molina, J.A (2012) 'Aspectos geográficos del entorno físico: morfología de la costa de Nueva Tabarca', Canelobre - Instituto Alicantino de Cultura Juan Gil-Albert n6o: 14-31

Martín, B (2003) 'La imagen turística de las regiones insulares: Las islas como paraísos', Cuadernos de Turismo n11: 127-137

Martínez Sanmartín, L.P (2012) 'El patrimonio como proceso social. Acerca de la isla de Nueva Tabarca', Tabarca. Utopía y realidad, Canelobre, Revista del Inst. Alicantino de Cultura Juan Gil-Albert n6o: 373-383

Mata Olmo, R (2006) 'Desarrollo sostenible, insularidad y gobierno del territorio: La experiencia del PTI de Menorca', Boletín de la Asociación de Geógrafos Españoles n41: 183198

Mazon, T (2006) 'Inquiring into residential tourism: the Coast Blanca Case', Tourism and Hospitality Planning and Development v3 n2: 89-97

Navalón-García, R (1995) Planeamiento urbano y turismo residencial en los municipios litorales de Alicante, Alicante: Instituto de Cultura Juan Gil-Albert

Parodi Arróniz, A (2012) 'La almadraba de Tabarca: un medio de vida entre la historia y la leyenda', Canelobre - Instituto Alicantino de Cultura Juan Gil-Albert n6o: 162-181 
---- (2015) 'Proyecto Tabarca Island', online:

http://lafogueradetabarca.blogspot.com.es/2015/o9/proyecto-tabarca-island.html accessed 11th February 2017

Pérez Burgos, J.M (2012) 'El sueño de Nueva Tabarca. Un anhelo utópico entre el deseo y la realidad', Canelobre - Instituto Alicantino de Cultura Juan Gil-Albert n6o: 50-63

Ramos, A.A and Bayle, J (1990) 'Management of living resources in the marine reserve of Tabarca island (Alicante, Spain)', Bulletin de la Société Zoologique de la France n114: 41-48

Ramos, A (2012) 'La reserva marina de la isla de Tabarca, una realidad después del sueño', Canelobre - Instituto Alicantino de Cultura Juan Gil-Albert n6o: 284-297

Soler Pascual, E (2012) 'Poblaciones idealizadas y viajeros en la España del XVIII: el caso de Nueva Tabarca', Canelobre - Instituto Alicantino de Cultura Juan Gil-Albert n6o: 65-77

Varela Botella, S (2007) 'Viaje a Nueva Tabarca. El territorio y la arquitectura. Breve descripción de una construcción que sobrevive a la utopía', in Semana de la arquitectura de la Comunidad valenciana, 2007, CTAA Colegio Oficial de Arquitectos de Alicante: http://www.ctaa.net/publio/Nueva\%2oTabarca.pdf - accessed nth February 2016 